ISSN:1308-8173

Geliş Tarihi: 08.05.2021
E-ISSN: 1308-8505

Kabul Tarihi: 12.07.2021
YIL: 2021

Online Yayın: 05.08.2021

ÖZGÜN ARAŞTIRMA
Cilt: 36 Sayı: 2 Sayfa: 479-496

Doi: $10.24988 /$ ije.202136215

\title{
Arabuluculuk Sürecine İdarenin Katılımı
}

\section{Gülümden ÜRCAN ${ }^{1}$}

\section{Özet}

Alternatif uyuşmazlık çözüm yollarından biri “arabuluculuk"tur. Türkiye'de 6325 sayılı Kanun özel hukukta arabuluculuk sürecini ve bunun temel ilkelerini düzenlemektedir. Arabuluculuk sayesinde taraflar, uyuşmazlığı kendi kararlarıla, bir mahkeme hükmüne ihtiyaç olmaksızın çözebilmektedir. Tarafsız bir üçüncü kişi olan arabulucu taraflara uyuşmazlığı müzakere etmede ve bir çözüme ulaşmada yardımcı olmaktadır. Uyuşmazlığın bir özel hukuk uyuşmazlığı olması halinde idare de arabuluculukta taraf olarak yer alabilir. Arabuluculuk sürecinde idareyi üç kişiden oluşan komisyon temsil etmektedir ve komisyon oybirliğiyle karar almak zorundadır.

Bu çalışmada arabuluculukta idare, idarenin temsili ve komisyon üyelerinin sorumluluğu konuları ele alınacaktır.

Anahtar Kelimeler: Arabuluculuk, İdare, 6325 Sayılı Arabuluculuk Kanunu

Jel Kodları: J52, K31, K40

\section{Participation of Administration in Mediation Process}

\begin{abstract}
"Mediation" is one of the alternative dispute resolution methods. In Turkey, Code 6325 regulates the basic principles and process of mediation in private law. Mediation allows the parties to solve the conflict among themselves without a court verdict. A mediator is a neutral third person who helps the parties negotiate the conflict and reach an agreement. In the case of a private law dispute, administrations can join the mediation process. Administrations are represented by three-person commission and the commission has to unanimously decide during the mediation process.
\end{abstract}

In this study, administration in mediation process, representation of administration and the obligations of commission members will be presented.

Keywords: Mediation, Administration, Code of Mediation Numbered 6325

Jel Codes: J52, K31, K40

\section{GİRIŞ}

Hukuk uyuşmazlıklarının dava dışı yollarla çözümünde alternatif metotlardan biri arabuluculuktur. Yabancılık unsuru içerenler dahil olmak üzere tarafların üzerinde serbestçe tasarruf edebileceği iş veya işlemlerden doğan özel hukuk uyuşmazlıklarının çözümlenmesinde arabuluculuğa başvurulabilir. Başvuru tarafların ya da bir tarafın serbest iradesine dayanabileceği gibi (ihtiyarî arabuluculuk) dava açmadan önce arabuluculuğa başvurulması bir kanun hükmüyle şart kılınmış da olabilir (dava şartı arabuluculuk). Hangi tür arabuluculuk olursa olsun süreç boyunca eşit haklara sahip olan taraflar müzakerelere katılmak, süreci devam ettirmek ya da sona erdirmek konusunda özgürdür. Arabuluculuk bir yargllama faaliyeti olmayıp, arabulucu da karar verici pozisyonda değildir. Tarafsız ve bağımsız bir üçüncü kişi olan arabulucu sistematik teknikler uygulayarak tarafların sorunu müzakere etmelerini, birbirlerini anlamalarını, iletişim sürecinin kurulmasını sağlamaktadır. Sürecin sonucu üzerinde yine taraflar belirleyicidir. Ancak tarafların çözüm üretemediklerinin

ATIF ÖNERİİ (APA): Ürcan, G., (2021). Arabuluculuk Sürecine İdarenin Katılımı. İzmir İktisat Dergisi, 36(2). 479-496.

Doi: $10.24988 /$ ije.202136215

${ }^{1}$ Dr. Öğr. Üyesi, Dokuz Eylül Üniversitesi, İktisadi ve İdari Bilimler Fakültesi, Kamu Yönetimi Bölümü, İzmir, Türkiye

EMAIL: gulumden.urcan@deu.edu.tr ORCID: 0000-0002-3460-537X 


\section{G. ÜRCAN}

anlașılması halinde arabulucu bir çözüm önerebilir; çözümü empoze edemez. Burada ele alınan sicile kayıtlı arabulucular tarafından mevzuata göre yürütülen nitelikli arabuluculuktur.

Adalet Bakanlığı istatistiklerine göre ${ }^{2}$ 2018/ Ocak - 2019/Aralık döneminde dava şartı iş uyuşmazlığ kapsamında arabulucu görevlendirilen 751.549 dosyadan \%64'ü anlaşma ile sonuçlanmıştır. Bu oran dava şartı ticarî uyuşmazlıklarda \%56'dır. Başvurunun bir yasa hükmüyle zorunlu tutulmadığı ihtiyarî arabuluculukta ise 2013 yilından 2019 yılsonuna dek 249.063 dosyanın \%97'si anlaşma ile sonuçlanmıştır. (ADB arabuluculuk istatistikleri)

Belediyeler, üniversiteler, bakanlıklar gibi kamu kurum ve kuruluşlarının da özel hukuk uyuşmazlıkları içinde bulunmaları mümkündür ve hukuken idarenin taraf olduğu her uyuşmazlığın idarî yargıda çözülmesi gibi bir genellemeye gidilemez. Uyuşmazlığın arabuluculuğa elverişliliği taraflardan birinin idare olup olmamasından bağımsız bir konudur. Bu çalışmada arabuluculuk sürecine idarenin katılımına ilişkin kurallar ele alınmaktadır. İncelemede arabuluculuk sürecinde "idare" kavramından ne anlașılması gerektiği, bunun yasal çerçevesi, idarenin görüşmelere nasıl katılacağı ve temsili, arabuluculuk müessesesinin ilkeleri bağlamında sürecin ișleyişi ve son olarak idarenin arabuluculuk komisyonu üyelerinin sorumlulukları gibi başlıca konulara temas edilecektir.

\section{GENEL OLARAK ARABULUCULUK}

Çok eski çağlardan beri bir uyuşmazlık çözüm yöntemi olan arabuluculuk modern anlamda 1960'lı yılların sonlarında Amerika'da sıkça kullanılmaya başlanmış, bir milat olarak kabul edilen 1976 yılındaki Rosceo Pound Konferansı sonrasında 90'larda İngiltere ve Fransa'nın da aralarında olduğu birçok ülke

${ }^{2}$ https://adb.adalet.gov.tr/Home/SayfaDetay/arabuluc uluk-istatistikleri arabuluculuk müessesesini kabul etmiștir. 2002 yılında ise UNCITRAL Milletlerarası Ticari Arabuluculuğa İlişkin Model Kanun kabul edilmiştir. $\mathrm{Bu}$ kanun ülkemizdeki arabuluculuk mevzuatına ilişkin çalışmalarda da esas alınmıştır. Aynı yıl, ülkemizdeki tasarının hazırlanmasında dikkate alınan bir diğer kaynak olan ve Avrupa Birliği'nde arabuluculuğun geliştirilip uzlaşma kültürünün yaygınlaştırılması, uygulanabilmesi hakkında değerlendirmeler içeren Medeni Hukukta ve Ticaret Hukukunda Uyuşmazlık Çözümüne İlişkin Alternatif Usuller Üzerine Yeşil Kitap hazırlanmıştır. Akabinde arabuluculuğa ilişkin Konsey yönergesi, rehber ilkeler ve tavsiye kararları ile $A B$ ülkelerinde yasal düzenlemeler gelișip olgunlaşmıștır (Pekcanitez, 2008: 248-249; Yeşilırmak, 2019: 27).

6325 sayılı Hukuk Uyuşmazlıklarında Arabuluculuk Kanunu uyarınca arabuluculuk, sistematik teknikler uygulayarak, görüşmek ve müzakerelerde bulunmak amacıyla tarafları bir araya getiren, onları birbirlerini anlamalarını ve bu suretle çözümlerini kendilerinin üretmesini sağlamak için aralarında iletişim sürecinin kurulmasını gerçekleştiren, tarafların çözüm üretemediklerinin ortaya çıkması hâlinde çözüm önerisi de getirebilen, uzmanlık eğitimi almış olan tarafsız ve bağımsız bir üçüncü kişinin katılımıyla ve ihtiyarî olarak yürütülen uyuşmazlık çözüm yöntemini ifade etmektedir (m.2/-b bendi).

Toplumda çıkarların korunması yargı yoluyla hukukî korumadan daha kapsamlı olup, menfaat çatışması üzerinde belirleyici olan devletin ve toplumun yapacağı çalışma, sırf devlet sayesinde gerçekleşemeyeceği için toplum geniş bir seçenekler dizisine ihtiyaç duymakta ve alternatif uyuşmazlık çözümlerinin önemi giderek artmaktadır. Bu noktada arabuluculukta yargı erkine sahip olmayan tarafsız bir üçüncü kişi, uyuşmazlığı ve çözüm yollarını müzakere eden tarafların 
uzlaşmasına yardımcı olmaktadır (Yıldırım, 2007: 339-340; Green Fishman, 2002). Arabuluculuğun yanı sıra erken tarafsız değerlendirme, müzakere, uzlaşma ve tahkim gibi başlıca alternatif uyuşmazlık çözüm yöntemleri de mevcuttur (Legal Information Institute, 2017). Arabuluculuğu da içine alan ve klsaca ADR (Alternative Dispute Resolution) olarak anılan alternatif uyuşmazlık çözümleri hızlı olması, daha az masraf gerektirmesi, gizliliğin esas alınması, tarafların çözüm üzerinde etkinliklerinin bulunması gibi birçok avantajı barındırmaktadır (Gilles, 2008: 266-267; Huerta, 2004). Kazan - kaybet ya da kaybet kaybet yerine, her iki tarafın da kazanması esasına dayalı arabuluculuk işleyişi yönünden yargılayıcı bir süreçten uzaktır; "haklı x haksız" tartışmasına değil, sorunun rasyonel bir biçimde ve tarafların iradesi doğrultusunda çözülmesine odaklanılmaktadır (Goodman, 2016: 3). Kamu yönetiminde de reform talebinin yoğunlaşarak artmasında adalet/yargı sisteminden hoşnutsuzluk başlıca etkilidir. Kamu hizmetlerinde kalite açısından ele alındığında da, örneğin sağlık sistemin hasta odaklı olması gibi yargı sisteminin de vatandaş odaklı olması, bireyin istekleri ve gereksinimlerinin kaliteli şekilde karşılanması öngörülür. Yargıda 'insan' unsuruna gereken önem verilerek insan biyolojik, sosyal, kültürel, psikolojik yönleri ile bir bütün olarak görülmelidir. Yargı sistemimizdeki sorunların büyüklüğü, atılacak adımların da radikal olmasını gerektirmektedir. (Özdemir, Süral ve Odaman, 2005: 167, 174, 179).

Mahkeme yargısı dışında alternatif bir uyuşmazlık çözüm yolu olan arabuluculuk Türk hukukunda 22.06.2012 tarihli Resmî Gazete'de yayımlanan 6325 sayılı Hukuk Uyușmazlıklarında Arabuluculuk Kanunu ile kanunî bir düzenlemeye kavuşmuştur. 7036 sayılı İş Mahkemeleri Kanunu'nun 01.01.2018 tarihinde yürürlüğe giren 3 . maddesi ile kanuna, bireysel veya toplu iş sözleşmesine dayanan işçi veya işveren alacağı ve tazminatı ile işe iade talebiyle açılan davalarda arabulucuya başvurulmuş olması özel bir dava şartı olarak düzenlenmiştir. Daha sonra 19.12.2018 günlü Resmî Gazete'de yayımlanan 7155 sayılı Kanun ile Türk Ticaret Kanunu'na Dava Şartı Olarak Arabuluculuk başlığı altında "Bu Kanunun 4 üncü maddesinde ve diğer kanunlarda belirtilen ticari davalardan, konusu bir miktar paranın ödenmesi olan alacak ve tazminat talepleri hakkında dava açılmadan önce arabulucuya başvurulmuş olması dava şartıdır" hükmü sevk edilmiş (m. 20), 6325 sayılı Arabuluculuk Kanunu'na yine aynı başlık altında 18/A maddesi eklenmiştir. Nihayet 28.07.2020 tarihli Resmî Gazete'de yayımlanarak yürürlüğe giren 7251 sayılı Kanun'un 59. maddesi ile 6502 sayılı Tüketicinin Korunması Hakkında Kanun'a dava şartı arabuluculuk hakkındaki 73/A maddesi eklenerek tüketici mahkemelerinde görülen ve maddedeki istisnalar dışındaki tüketici uyuşmazlıkları yönünden de dava açmadan önce arabuluculuğa başvuru zorunlu kılınmıştır.

Hukukumuzda arabuluculuk, ancak tarafların üzerinde serbestçe tasarruf edebilecekleri iş veya işlemlerden doğan özel hukuk uyuşmazlıklarının (aile içi şiddet iddiasını içeren uyuşmazlıklar hariç) çözümlenmesinde uygulanan alternatif bir uyuşmazlık çözüm yöntemidir. Söz konusu uyuşmazlığın yabancılık unsuru taşıması arabuluculuğa başvurulmasına engel teşkil etmemektedir.

Arabuluculuğun iradî olması nedeniyle taraflar arabulucuya başvurmak, süreci devam ettirmek, sonuçlandırmak veya bu süreçten vazgeçmek konusunda serbesttirler. Dava şartı arabuluculuk bakımından, dava açılmadan önce arabuluculuk yoluna başvuru zorunluluğu getirilmesinin bu ilkeyi ortadan kaldırmadığı, bu yolların sırf kişilerin hak aramalarını imkânsız hâle getirmek amacıyla oluşturulmuş etkisiz ve sonuçsuz yöntemler olmadığı sürece hak arama özgürlügüne aykırı kabul edilemeyeceği Anayasa Mahkemesi'nin 10.07.2013 T., 2012/94 E., 2013/89 K. sayılı iptal talebinin reddine dair kararında ifade edilmiştir (RG. 28893, 25.01.2014). İş 
Mahkemeleri Kanunu'nun 3. maddesiyle getirilen iş hukuku uyuşmazlıklarında dava şartı arabuluculuk düzenlemesinin iptali için açılan dava da Anayasa Mahkemesi'nce oybirliğiyle reddedilmiștir. ${ }^{3}$ Esasen arabuluculuk yargllamanın alternatifi olarak değil tamamlayıcısı olarak getirildiğinden ve süreç anlaşmayla sonuçlanmadığında dava yoluna başvuru imkânı açık olduğundan arabulucuya zorunlu başvuru yargllama hakkının ihlal edilmesi anlamına gelmemektedir (Kurt, 2018: 431).

Bir yarglama faaliyeti olmayan arabuluculukta, arabuluculuk usulü faaliyetin yürütülmesine dair yöntem ve süreç anlamında kullanılmaktadır; yoksa kastedilen teknik anlamda basit usul-yazılı usul gibi bir yargılama usulü değildir (Pekcanıtez, Atalay ve Özekes, 2020: 631). Arabuluculuk süreci hazırlık, başlangıç, inceleme-araştırma, müzakere ve sonuç aşamalarından oluşmaktadır ${ }^{4}$. Arabuluculuk faaliyetinin fiilen başlamasından önceki dönemi de kapsayabilen hazırlık aşamasında hem taraflar hem arabulucu sürece hazırlanır. Arabuluculuğa ilişkin temel ilke ve kuralların belirtilip teyit edildiği, arabulucunun ve tarafların açılış konuşmalarının yapıldığı başlangiç aşamasından sonraki inceleme ve araştırma aşamasında ise arabuluculuğa başvuru konusu olan uyuşmazlıkla ilgili olayların, duygular ve diğer önemli hususların ortaya çıkarılması, anlaşmaya yönelik başlıkların belirlenmesi ve bir sonraki aşamanın gündeminin hazırlanması amaçlanır. Akabinde taraflarca uyuşmazlık konuları, ihtiyaçlara ve menfaatlere yönelik hususlar müzakere aşamasında müzakere edilerek, arabulucunun da teşvikiyle bir çözüme, sonuca ulaşmaya çalışılır. Tarafların çözüm üretemediklerinin ortaya çıkması halinde arabulucunun çözüm önerisi getirebilmesi, esasen hukukî bilgi paylaşımı olmayıp, onların iradelerine uygun olarak görüşmelerde dile

3 11.07.2018 T., 2017/178 E., 2018/82 K. (RG. 11.12.2018 T., S. 30622). Arabuluculuğa başvurunun zorunlu tutulmasının arabuluculuğun ruhuna ve getirilmiş bir öneriye arabulucu tarafından işaret edilebileceği gibi, gündeme gelmemiş yeni bir öneri de arabulucu tarafindan sunulabilir (Odaman ve Karaçöp, 2018: 47). Sürecin mutlaka anlaşma ile sonuçlanması zorunluluğu bulunmamaktadır. Karar taraflara ait olup, onların uyuşmazlığı sulhen sonuçlandırmaları bir ödev değil, haktır (Yıldırım, 2007: 356). Tam olarak ya da kısmen anlaşma sağlanabileceği gibi, tarafların hiçbir konuda anlaşamamaları da ihtimal dahilindedir. Sonuç ne yönde olursa olsun, arabuluculuk faaliyetinin sonunda tarafların anlaştıkları, anlaşamadıkları veya faaliyet başka sebeple sona erdi ise bu sebep yazılmak yoluyla "son tutanak" düzenlenir. Bir anlaşmaya varılmış ise ve tarafların istemesi halinde "anlaşma belgesi" düzenlenebilir. Anlaşmaya varılan hususlarda artık dava açılamaz ve anlaşma belgesi icra edilebilir. Taraflar ve avukatları ile arabulucunun birlikte imzaladıkları anlaşma belgesi, icra edilebilirlik şerhi aranmaksızın ilam niteliğinde belge sayılır (6325/m. 18).

\section{ARABULUCULUK SÜRECİ VE İDARE}

\subsection{Arabuluculukta İdare Kavramı}

Genel olarak idare, devletin yanı sıra sendika, vakıf, şirket gibi özel hukuk örgütlenmelerinde de görülen, yani hem kamu hukuku hem özel hukuk ile ilgili bir kavramdır. İdare hukuku anlaminda idare ise "kamu idaresini" ele almaktadır. Kuruluşu ve çalışması kanunlarla düzenlenen, kamu yararı gözeten ve bu amacı gerçekleştirebilmek için kamu gücüyle donatılan kamu idareleri, özel kişiler karşısında üstün konumdadırlar ve onların rızası hilafına da işlem yapabilirler. (Gözler ve Kaplan, 2016: 7)

6325 sayılı Kanun kapsamında arabuluculuk hukuk uyuşmazlıklarının çözümünde kullanılabilen bir alternatif çözüm yoludur. İdarenin de bir özel hukuk uyuşmazlığına taraf

ilkelerine aykırı olduğu görüşü için bkz. Ekmekçi, Özekes ve Atalı, 2018: 110 vd.

4 Geniş bilgi için bkz. Temel Arabuluculuk Eğitimi Katılımcı Kitabı, Nisan 2019 (https://adb.adalet.gov.tr) 
olması elbette mümkündür. Bir tarafında idarenin yer aldığı her sözleşme idarî sözleșme niteliği taşımayıp, idare (abonman sözleşmeleri, kira/satım sözleşmeleri, kamu ihale sözleşmeleri, hizmet akitleri gibi) özel hukuk sözleşmeleri de bağıtlayabilmektedir. Böyle hukukî işlemlerden, özel hukuk sözleşmelerinden doğan uyuşmazlıklar da tabiatıyla idarî yargının değil, adlî yargının görev alanına girmektedir (Gözler ve Kaplan, 2018: 399). Tarafların üzerinde serbestçe tasarruf edebilecekleri bir özel hukuk iş veya işleminden kaynaklanması kaydıyla, taraflardan birinin idare olması uyuşmazlığı arabuluculuğa elverişli olmaktan çıkarmamaktadır. Bilakis, aşağıda daha geniş ele alınacağı üzere, iş uyuşmazlıklarında görüldüğü gibi bazı hallerde dava açmadan önce arabuluculuğa başvuru, idarenin taraf olduğu uyuşmazlıklar bakımından da zorunlu tutulmuştur. İdarenin taraf olduğu özel hukuk sözleşmelerinden doğan uyuşmazlıklar 6325 sayılı Kanun kapsamında değerlendirilmekte (Üstün Fiş, 2020: 14; Çapar, 2020: 2529) iken, idarenin kamu gücünü kullanarak gerçekleştirdiği idarî işlemlerden kaynaklanan uyuşmazlıklar ise özel hukukun değil, ayrı bir yargı yolu olan idarî yargının konusunu oluşturmakta ve 6325 sayılı Kanun kapsamında yer almamaktadır.

İdarenin taraf olduğu uyuşmazlıkların da alternatif yöntemlerle çözülebilmesine olanak tanınması, zaman ve masraftan tasarruf, verimlilik, idare ile birey arasında daha ılımlı tutumlarla sürecin dostane bir şekilde yürütülmesi gibi birçok avantajı beraberinde getirmektedir. Adeta yerleşik bir uygulama şekline dönüşmüş ve siklıkla eleştirilen idarenin bir anlaşmazlığı gidermek, bir işlemi düzeltmek için mahkeme kararı beklemesi idareye olan güveni de sarsmakta, yılgınlığa sebep olabilmektedir. Bunun yerine birey ile idare uyuşmazlığı ortadan kaldırmak için birlikte gayret gösterdiğinde idareye duyulan güven artacağı gibi kamu hizmeti ilișkisi daha sağlıklı bir şekilde yerine getirilebilecektir (Hasoğlu, 2016: 1988-1989; Canbolat, 2018:
100). Doktrinde iş uyuşmazlıkları vesilesiyle dile getirildiği haliyle "zorunlu arabuluculuk kurumunun başarılı olması, idarenin bu süreçlerde inisiyatif almasına bağlıdır. Aksi taktirde en büyük işveren olan Devletin taraf olduğu davalarda uzlaşma asla sağlanamamış olacaktır" (Çil, 2018a : 44).

Aslında idarenin taraf olduğu özel hukuk uyuşmazlıklarının bir mahkeme kararı beklenmeksizin alternatif yollarla çözümü ilk kez Arabuluculuk Kanunu ile benimsenmiş değildir. Örneğin 02.11.2011 T., 28103 sayılı RG'de yayımlanan 659 Sayılı Kanun Hükmünde Kararname'ye göre "idarelerin adli yargıda dava açmadan veya icra takibine başlamadan önce karşı tarafi sulhe davet etmesi esastır. Idareler, kendi aleyhlerine dava açılacağını veya icra takibine başlanılacağını öğrenmeleri durumunda da karşı tarafi sulhe davet edebilirler" (m. 9). Fakat belediye, köy, il özel idaresi gibi mahalli idareler, Sosyal Güvenlik Kurumu ile düzenleyici ve denetleyici Kurumlar 659 sayılı Kanun Hükmünde Kararname'nin kapsamı dışındadır (Erzurumlu, 2015: 76). 1938 yılında kabul edilen 3533 sayılı Kanun'da umumi, mülhak ve hususi bütçelerle idare edilen daireler ve belediyelerle sermayesinin tamamı devlete veya belediyeye veya hususi idarelere ait olan daire ve müesseseler arasında çıkan ihtilaflardan adliye mahkemelerinin görevine girenlerin zorunlu tahkim yoluyla çözülmesi esası benimsenmiştir. Hatta bundan daha geriye gidildiğinde 07.04.1924 tarihli Resmî Gazete'de yayımlanan Köy Kanunu'nda iki köy arasındaki çekişmeli sınırların çizilmesi için hükümet emriyle uyuşmazlık içindeki köylerin müzakere edeceğine ve ihtiyar meclislerinin köylüler arasındaki uyuşmazlıklarda, modern anlamda nitelikli arabuluculuk şeklinde olmamakla birlikte, arabuluculuk 
yapabileceğine ve sulhe dair düzenlemeler kabul edilmiştir5.

Arabuluculuk Kanunu açısından "idare" teriminden ne anlaşılması gerektiği 6325 sayılı Kanun'un tanımlara ilişkin 2. maddesinde belirtilmiştir. Düzenlemeye göre idare; 10/12/2003 tarihli ve 5018 sayılı Kamu Malî Yönetimi ve Kontrol Kanununa ekli (I), (II), (III) ve (IV) sayılı cetvellerde yer alan idare ve kurumlar ile 5018 sayılı Kanunda tanımlanan mahalli idareler ve bu idareler tarafindan kurulan işletmeleri, özel kanunla kurulmuş diğer kamu kurum, kurul, üst kurul ve kuruluşları, kamu iktisadi teşebbüsleri ile bunların bağlı ortaklıkları, müessese ve işletmelerini, sermayesinin yüzde ellisinden fazlası kamuya ait diğer ortaklıkları ifade etmektedir (-e bendi). Hukuk Uyuşmazlıklarında Arabuluculuk Kanunu Yönetmeliği'nin 4/-i bendinde de aynı yönde hüküm yer almaktadır. Dolayısıyla, idarenin arabuluculuk sürecine katılması sırf kamu tüzel kişiliği bulunmasından ibaret olmayıp, bundan daha geniş bir kapsamda ele alınmıştır. Öyle ki, ticaret şirketi gibi özel hukuk tüzel kişisi de olsa, sermayesinin yarıdan fazlası kamuya ait ise, bu şirket arabuluculuk mevzuatına göre "idare" sayılmaktadır.

Kamu Malî Yönetimi ve Kontrol Kanunu'na ekli cetvellere göre genel bütçe kapsamındaki kamu idareleri (örneğin TBMM, Cumhurbaşkanlığl, Anayasa Mahkemesi, Yargıtay, Danıștay, Hakimler ve Savcılar Kurulu, Bakanlıklar, TÜİK, Afet ve Acil Durum Yönetimi Başkanlığı, Gelir İdaresi Başkanlığı, Göç İdaresi Genel Müdürlüğü, Avrupa Birliği Başkanlı̆̆ı); özel bütçeli idareler (YÖK, üniversiteler ve yüksek teknoloji enstitüleri, Atatürk Kültür, Dil ve Tarih Yüksek Kurumu, Atatürk Kültür Merkezi, Türkiye Bilimsel ve Teknolojik Araștırma Kurumu, Türkiye Bilimler Akademisi, Vakıflar Genel Müdürlüğü, GAP Bölge Kalkınma İdaresi, Özelleştirme İdaresi Başkanlığı,

\footnotetext{
${ }^{5}$ Geniș bilgi ve diğer örnekler için bkz. Özbek, 2005: 56105.

${ }^{6}$ Ancak 2937 Sayılı Devlet İstihbarat Hizmetleri ve Milli İstihbarat Teşkilatı Kanunu'nun 30. maddesine göre MíT'in tarafı olduğu hukuk uyuşmazlıklarında, dava
}

Kamu Denetçiliği Kurumu, Yurtdıșı Türkler ve Akraba Topluluklar Başkanlı̆̆ı, Devlet Su İşleri Genel Müdürlügü, Türkiye Su Enstitüsü, Türkiye İlaç ve Tıbbî Cihaz Kurumu, Türkiye İnsan Hakları ve Eşitlik Kurumu gibi); düzenleyici ve denetleyici kurumlar (örneğin SPK, Bilgi Teknolojileri ve İletişim Kurumu, BDDK, Kamu İhale Kurumu, Kişisel Verileri Koruma Kurumu) ile sosyal güvenlik kurumları (SGK ve Türkiye İş Kurumu Genel Müdürlüğü) arabuluculuk müessesesi bakımından idaredir. Yine belediyeler gibi mahallî idareler ile bunlar tarafından kurulan işletmeler, KİT'ler ile bağlı ortaklıklar ve sermayesinin \%50'sinden fazlası kamuya ait her türlü ortaklık 6325 sayılı Kanun uyarınca idare kavramı kapsamındadır 6 .

\section{2. İdarenin Arabuluculuk Görüşmelerine Katılması}

İdarenin kendisine karşı arabuluculuk başvurusundan haberdar olabilmesi, arabuluculuk ve toplantı davetinin yapılabilmesi için adres, kayıtlı elektronik posta adresi ve telefon numarasını internet sitesinde yayınlaması Arabuluculuk Yönetmeliği'nde öngörülmüștür (m. 18/f. 2)7. Arabulucuların (genel olarak, her türlü iletişim vasıtasını kullanarak tarafları bilgilendirebilmesi ve ilk oturuma davet edebilmesi mümkün ise de) idarenin taraf olduğu uyuşmazlıklarda görüşmeler kapsamında yapacakları davetler için öncelikle bu bilgileri esas almaları gerekmektedir. Dava şartı arabuluculukta, geçerli bir mazeret olmadan ilk toplantıya katılmayan taraf ileride muhtemel bir davada kısmen ya da tamamen haklı çıssa bile yarglama giderlerinin tamamından sorumlu tutulacağından ve bu taraf lehine vekalet ücretine hükmedilmeyeceğinden (6325/m. 18 /A), ilk oturuma katılmak özel bir önem taşımaktadır. İleri sürülen taleplerin dayanaksız, hukuka aykırı olduğu düşünülse, arabuluculuk sürecinde anlaşma sağlanmayacağı öngörülse

şartı olarak öngörülen arabuluculuk dâhil, arabuluculuk usulü uygulanmamaktadır.

${ }^{7} \mathrm{Bu}$ doğrultuda örneğin Dokuz Eylül Üniversitesi de arabuluculuk komisyonunu oluşturarak iletişim bilgilerini internet sitesinde yayınlamıştır. 
dahi bilhassa ilk oturuma katılma hususunda hassasiyet gösterilmelidir.

Kural olarak arabuluculuk müzakerelerine taraflar bizzat, kanunî temsilcileri veya avukatları aracılığıyla katılabilmektedirler (Arabuluculuk Kanunu m. 15/f. 6).8 7036 sayılı İş Mahkemeleri Kanunu'nun dava şartı arabuluculuğu düzenleyen 3. maddesinin getirdiği imkânla işverenin yazılı belgeyle yetkilendirdiği çalışanı da görüşmelerde işvereni temsil edebilmekte ve son tutanağı imzalayabilmektedir (f. 18). Fakat idarenin katılımı bakımından özel düzenleme getirilmiştir. Buna göre arabuluculuk müzakerelerinde idareyi, "üst yönetici tarafından belirlenen iki üye ile hukuk birimi amiri veya onun belirleyeceği bir avukat ya da hukuk müşavirinden oluşan komisyonun" temsil etmesi zorunludur (Arabuluculuk Kanunu m. 15/f. 8). İdarenin de bir iş sözleşmesinin tarafı olması, işveren sıfatı taşıyabilmesi pekala mümkündür. Yukarıda belirtildiği gibi İş Mahkemeleri Kanunu'nun 3. maddesine göre dava şartı arabuluculukta işverenin yazılı belgeyle yetkilendirdiği çalışanının da görüşmelerde işvereni temsil edebilmesi ve son tutanağı imzalayabilmesine olanak tanınmıștır. Fakat bu halde de yani arabuluculuğa başvuru konusu bir iş sözleşmesinden kaynaklandığında da idarenin bir çalışanını yazılı belgeyle yetkilendirerek müzakereye katılması mümkün olmayıp, yasada belirlenen kişilerden oluşan üç kişilik komisyonla katılım gereklidir.

Arabuluculuk Kanunu Yönetmeliği'nin 18. maddesi başlı başına idarenin temsili konusuna ayrılmıştır. $\mathrm{Bu}$ düzenlemede de arabuluculuk müzakerelerinde idareyi temsil edecek komisyonun, üst yönetici tarafından belirlenen iki üye ile hukuk birimi amiri veya onun belirleyeceği bir avukat ya da hukuk müşavirinden oluşacağı tekrarla belirtilmiştir. "Üst yönetici"den ne anlaşılması gerektiği mevzuatta düzenlenmiş olup, üst yönetici

\footnotetext{
8 Uyuşmazlığın çözümüne katkı sağlayabilecek uzman kişiler de müzakerelerde hazır bulundurulabilir.
}

bakanlıklarda müsteşarı; il özel idarelerinde valiyi; belediyelerde belediye başkanını; diğer kamu idarelerinde ise kendi mevzuatına göre tanımlanan en üst yöneticiyi veya kurulu ifade etmektedir (Arabuluculuk Yönetmeliği m.4/-o bendi). Üyelerin görev süresi 2 yıldır ve süresi dolan üye yeniden seçilebilir (Arabuluculuk Yönetmeliği m. 18).

Hukuk biriminin veya kurum avukatının olmadığı hallerde komisyon üyelerinin tamamı üst yönetici tarafından belirlenir. Yedek komisyon üyeleri de aynı usulle seçilir. Kanunda yedek üyelerden söz edilmemesine karşllık yönetmeliğin bu hususta düzenleme getirmesinin, kanunu genişletmesi hasebiyle hukuka aykırı olduğu akla gelebilir ise de, doktrinde bu düzenlemenin, üçüncü kişiler açısından aleyhe değil, tam tersine sürecin çeşitli mazeretlerle aksamasını engelleyici bir işlev taşıdığı ve esasen tamamlayıcı mahiyette olduğu değerlendirilmektedir. (Üstün Fiş, 2020: 17).

Ayrıca Yönetmelik'e göre komisyon kendisini vekil ile temsil ettiremez. Hukuk birim amiri ya da onun tarafından belirlenecek bir avukat yahut hukuk müşaviri zaten komisyonun doğal üyesidir. Fakat bu şekilde komisyonda yer almayan bir avukatın idareyi temsilen vekaletnameye dayanarak arabuluculuk görüşmelerine katılması söz konusu değildir.

Bilindiği gibi idarelerin merkez ve taşra teşkilatları olabilmektedir. Tüm arabuluculuk görüşmelerine sadece merkezde oluşturulan bir komisyonun katılması oldukça güçlük arz edebileceğinden, yönetmelikte taşra teşkilatlarında da komisyon kurulmasına imkân sağlanmıştır. Öte yandan, dava şartı arabuluculukta başvuru, uyuşmazlığın konusuna göre yetkili mahkemenin bulunduğu yer arabuluculuk bürosuna (arabuluculuk bürosu kurulmayan yerlerde ise görevlendirilen yazı işleri müdürlügüne) yapılmaktadır $(6325 / \mathrm{m}$. 18/A/f. 4) ve 


\section{G. ÜRCAN}

arabuluculuk görüșmeleri, taraflarca aksi kararlaştırılmadıkça, arabulucuyu görevlendiren büronun bağlı bulunduğu adli yargı ilk derece mahkemesi adalet komisyonunun yetki alanı içinde yürütülmektedir (f. 17). Dava şartı arabuluculuk kapsamında olan ve idarenin sıklıkla taraf olarak yer aldığı iş uyuşmazlıkları bakımından yetkili mahkeme, davalı gerçek veya tüzel kişinin davanın açıldığı tarihteki yerleşim yeri mahkemesi ile işin veya işlemin yapıldığı yer mahkemesidir (İş M.K. m 6). Buna göre arabuluculuk başvurusu idarenin merkezinin bulunduğu yerde yapılabileceği gibi, örneğin ișçi taşra teșkilatında çalışan bir kimse ise işyerinin bulunduğu yerdeki arabuluculuk bürosuna da başvuru yapabilir.

Arabulucu görevlendirmeyi yapan adliye arabuluculuk bürosunun yer yönünden yetkili olup olmadığını re'sen dikkate alamayacağından, idarenin karşı taraf olarak yer aldığı uyuşmazlıklarda en geç ilk toplantıda yetki itirazında bulunması gereklidir. Yetki itirazı üzerine dosya derhal ilgili sulh hukuk mahkemesine gönderilmek üzere arabulucu tarafından büroya teslim edilecektir. İtirazın kabulü halinde kararın tebliğinden itibaren bir hafta içinde yetkili büroya başvurulabilir. Yetki itirazı reddedilirse aynı arabulucu yeniden görevlendirilecektir (İş M.K. m. 3/f. 9; 6325 sK. m. 18/A/f. 8).

Arabuluculuk komisyonu üyeleri bu kapsamdaki görevleri uyarınca ilgili özel ve kamu kurum ve kuruluşları ile sekretarya aracılığıyla yazışma yetkisine sahiptir. Kurum ve kuruluşlar tarafından komisyona ivedi olarak cevap verilmesi gerekmektedir. İlgili kurum ve kuruluşların yazışmalarda gereken hassasiyeti göstermeleri sürecin aksamadan işleyebilmesi, komisyonun ihtiyaç duyduğu belge ve bilgilere erişimi, keza müzakerenin etkinliği ve sağlıklı bir sonuca ulaşılabilmesi bakımından önem taşımaktadır. Görüşmelerde idareyi temsil eden komisyonun, arabuluculuk müzakereleri sonunda gerekçeli bir rapor düzenlemesi gereklidir ve yasada raporun beș yıl boyunca saklanması yükümlülüğü getirilmiştir (Arabuluculuk Kanunu m. 15/f. 8) Raporun saklanmasına ilişkin gerekli tedbirler komisyonun sekretarya hizmetlerini yürüten birim tarafından alınacaktır (Arabuluculuk Yönetmeliği m. 18/f. 6).

\subsection{Arabuluculuk Sürecinin İlke ve Kuralları Bakımından İdarenin Durumu}

\subsubsection{Genel Olarak}

Arabuluculuğa ilişkin iradî olma ve eşitlik, gizlilik, beyan ve belgelerin kullanılamaması gibi temel ilkeler idarenin katıldığı arabuluculuk sürecinde de geçerliliğini korumaktadır. İdarenin taraf olduğu arabuluculukta da idarenin diğer taraf karşısında üstünlüğü, kamu gücünü kullanarak onun iradesi hilafına işlem yapabilmesi söz konusu değildir. Arabuluculuk Kanunu ve Yönetmeliği'nde belirtildiği gibi taraflar, gerek arabulucuya başvururken gerekse tüm süreç boyunca eşit haklara sahiptirler. Taraflardan biri arabuluculuk sürecinin dişında bırakılamayacağı gibi söz hakkı da diğerine göre kısıtlanamaz.

Arabuluculuğa egemen bir diğer ilke gizlilik ilkesidir. $\mathrm{Bu}$ ilke gereğince arabulucu, arabuluculuk faaliyeti çerçevesinde kendisine sunulan veya diğer bir şekilde elde ettiği bilgi ve belgeler ile diğer kayıtları gizli tutmakla yükümlü olduğu gibi, taraflar ve görüşmelere katılan diğer kişiler de bu konudaki gizliliğe uymak zorundadırlar. Gizliliğin ihlali nedeniyle bir kimsenin hukuken korunan çıkarlarının zarar görmesine yol açan kişi 6 aya kadar hürriyeti bağlayıcı cezaya mahkum edilebilir (Arabuluculuk Kanunu m.33). Ancak belirtilen gizlilik kuralı mutlak emredici nitelikte değildir ve taraflarca aksinin kararlaştırılması mümkündür (Arabuluculuk Kanunu m. 4).

Arabuluculuk bir yarglama faaliyeti olmadığından, tarafların ispat yükü bulunmamaktadır. Taraflar diler ise uyuşmazlık konusuyla ilgili ellerinde var olan kayıt ve belgelerini, delillerini sunabilirler ve inceleme aşaması ile müzakereyi bunlar 
üzerinden sürdürebilirler. Fakat Arabuluculuk Kanunu'nun 15. maddesinin 4. fikrasinda düzenlendiği üzere, niteliği gereği yargısal bir yetkinin kullanımı olarak sadece hakim tarafından yapılabilecek işlemler arabulucu tarafından yapılamaz. Örneğin arabulucu keşfe karar veremez yahut tanık dinleyemez. Öte yandan tarafların bilirkişi incelemesine ihtiyaç duyabilmeleri ihtimal dahilindedir ve söz gelimi kusur durumu ve zarar miktarının tarafsız bir bilirkiși marifetiyle incelenip değerlendirilmesi, tutarın hesap unsurlariyla ortaya konulması anlaşma sağlanması açısından fayda sağlayabilecektir. İdareyi temsilen sürece katılan komisyon üyeleri böyle bir bilirkişi raporunu, uzman görüşünü göz önünde bulundurarak muhtemel bir davanın sonuçlarını daha doğru değerlendirebileceklerinden somut verilere göre daha kolay sorumluluk alabileceklerdir (Karaarslan, 2019: 80).

\subsection{2. İş Uyuşmazlıkları Yönünden Özellik Arz Eden Hususlar}

İdare bizzat nezdinde çalıştırdığı işçilerin işçilik alacaklarından "işveren" sıfatıyla zaten sorumludur. Dolayısıyla doğrudan doğruya bu sıfatla arabuluculukta taraf olması mümkündür. Ayrıca hizmetlerin Kamu İhale Kanunu veya diğer kanun hükümleri çerçevesinde hizmet alım yolu ile yüklenici aracılığıyla yerine getirilmesi de mümkün olduğundan, idareler asıl (üst) işveren - alt işveren iliş̧isi bağlamında alt işveren işçilerinin alacaklarından İş Kanunu'nun 2. maddesi uyarınca asıl işveren sıfatıyla birlikte sorumluluk taşımaktadır. Yine İş Kanunu'nun 36. maddesine göre genel ve katma bütçeli dairelerle mahalli idareler veya kamu iktisadi teşebbüsleri yahut özel kanuna veya Cumhurbaşkanlığı kararnamesine dayanılarak kurulan banka ve kuruluşlar; asıl işverenler müteahhide verdikleri her türlü bina, köprü, hat ve yol inşası gibi yapım ve onarım işlerinde

\footnotetext{
${ }^{9}$ İşçinin ișverence ișe bașlatılmaması halinde en az dört en çok sekiz aylık ücret tutarında ödenmesi gereken tazminattır.
}

çalışan işçilerden müteahhit veya taşeronlarca ücretleri ödenmeyenlerin bulunup bulunmadığının kontrolü ya da ücreti ödenmeyen iş̧̧inin başvurusu üzerine, müteahhitten veya taşeronlardan istenecek bordrolara göre varsa ödenmeyen ücretleri hakedişlerden öderler... Bu sorumluluk her hakediş dönemi için ücret alacaklarının üç aylık tutarıyla sinırlıdır. Aynı Kanun'un bazı kamu kurum ve kuruluşlarında çalışanların kıdem tazminatına ilişkin 112. maddesi bağlamında da merkezî yönetim kapsamındaki kamu idarelerinin ve yerel yönetimlerin kıdem tazminatı alacaklarından sorumlulukları bulunmaktadır.

İş Kanunu'nun 18 ila 21. maddelerinde düzenlendiği haliyle feshe karşı koruma kapsamında iş sözleşmesi feshedilen bir işçinin feshin geçerli nedene dayanmadığı yahut fesih bildiriminde sebep gösterilmediği, şekil kurallarına uyulmadığı iddialarıyla bildirimin tebliğinden itibaren bir ay içinde arabulucuya başvurması zorunludur (m. 20). Arabuluculuk faaliyeti sonunda anlaşma sağlanır ise anlaşmanın işçinin işe başlatılacağı tarihi, feshi izleyen ve işçinin çalıştırılmadığı sürede en çok dört aya kadar doğmuş bulunan ücret ve diğer hakların parasal tutarını ve iş güvencesi tazminatının ${ }^{9}$ parasal miktarın içermesi yasal bir zorunluluktur. Aksi halde 21 . maddeye göre anlașma sağlanamamıș sayılmaktadır. $\mathrm{Bu}$ sebeple arabuluculuk komisyonunun anlaşma belgesinde bu unsurların yer almasina dikkat etmesi gereklidir. Hazırlanacak komisyon raporunda da emredici hükümde aranan söz konusu hususlarla anlaşma sağlandığ $ı$ ortaya konabilecektir.

Dikkat edilmesi gereken bir diğer nokta; ișe iade talebi ile alt işverenlik ilişkisinin bir arada bulunduğu hallerde, alt ișveren işçisi ișe iade talebiyle arabulucuya başvurduğunda anlaşma sağlanabilmesi için, asıl işveren ve alt 


\section{G. ÜRCAN}

ișverenin arabuluculuk görüșmelerine birlikte katılmaları ve iradelerinin birbirine uygun olmasıdır. 0 itibarla, yukarıda belirtildiği gibi idarenin hizmet alım yoluna gittiği ilişkilerde yüklenici firma/alt işveren ișçilerinin işe iade taleplerinde bu esasa riayet edilmesi zarurîdir ${ }^{10}$. Örneğin işverenlerden birinin ilk toplantıya katılıp işe başlatma ve sonuçları hakkında kabul yönünde beyanda bulunması, ardından düzenlenen toplantıya diğer işverenin katılarak aynı yönde beyanının alınması yeterli olmayacaktır. Son tutanağın imzalanıp anlaşma sağlanan müzakereye her iki işverenin birlikte katılması ve aynı şekilde anlaşma yönünde irade açıklamasında bulunmaları gereklidir. (Çil, 2018a: 44)

Bazı Yargıtay kararlarına göre "asıl işveren-alt işveren ilişkisinin geçerli olup olmadığı veya muvazaaya dayanıp dayanmadığına yönelik re'sen yapılmasi gereken yargisal denetim, ilişkinin taraflarının, yani asıl işveren ve alt işverenin davada yer almalarını ve kendi hukuklarını koruyacak açıklama ve ispat haklarını zorunlu kılmaktadır. Aksince bir düşünce...adil yargılanma hakkına ve... hukuki dinlenilme hakkına aykırılık teşkil eder. Buna göre, işe iade davalarına özgü olarak, asıl işveren-alt işveren ilişkisinin söz konusu olduğu davalarda, davalı tarafyönünden bir çeşit şekli (usûlî) bakımdan mecburi dava arkadaşlığının mevcut olduğu kabul edilmelidir"11.

Sadece alt işverenin taraf gösterildiği bir arabuluculuk başvurusu sonucunda başvurucu işçi ile kendi işvereni olan alt işveren mutabakata varsalar dahi, bu durum idare yönünden bağlayıcılık taşımayacak ve sürecin 7036 sayılı İş Mahkemeleri Kanunu'nun 3. maddesinin 15 . fikrasına aykırı şekilde yürütüldügü savunulabilecektir. Madde gerekçesinde hukukî dinlenilme hakkından, bu düzenleme ile hem işçi hem de işveren tarafının

\footnotetext{
10 İșe iade sürecinin her iki işvereni de ilgilendirmesi, 1 aylık başvuru süresinin kısalığı nedeniyle bir işveren ile süreç sonuçlanıncaya kadar diğeri hakkındaki başvuru süresinin kaçırılma riski gibi sebeplerle düzenlemeyi yerinde bulan görüş (Ekmekçi ve diğerleri, 2018: 147148).
}

hak ve çlkarlarının daha iyi șekilde korunmasının amaçlandığından söz edilmektedir. Canbolat'ın dile getirdiği haliyle "hüküm yeni sorunlar çıkaracak niteliktedir ve isabetli değildir...Bu arabuluculuğun özüne de ters(tir). Hukukun temel ilkelerinden biri taraf iradelerinin örtüştüğü durumda anlaşma gerçekleşmiş olur. Anlaşan tarafla anlaşma, anlaşmayan tarafla da anlaşmama tutanağı tutulur. Ayrica taraflardan kime husumet yöneltilmişse müzakere onunla yapılır..." (Canbolat, 2020: 173-174). Aslında muvazaaya dayanmayan, hukuka uygun ve geçerli bir alt işverenlik ilişkisinde iş sözleşmesinin tarafları işçi ile (alt) işverendir; asıl işveren bu sözleşmeye taraf olmayan üçüncü kişi konumundadır ${ }^{12}$. İş sözleşmesini fesheden de elbette asıl işveren değil, alt işverendir. Fesih yetkisi bulunmayan asıl işverene işçinin işe iade talebinin kabul edilip edilmeyeceği hususunda inisiyatif tanınması hatta bundan öte belirleyici anlaşma iradesi ve kabul beyanı aranmasının sözleșme teorisine de, alt işverenlik ilişkisinin hukukî niteliğine de uygun düşmediği kanaatindeyiz. Neticede bir işverenin geçersiz feshin ardından müzakereler sonucunda kendi ișçisini işe başlatma ve bu hususta anlaşma iradesi, o sözleşmeye taraf olmayan bir üçüncü kişinin de kabulü şartına bağlanmamalıdır. Fiilen de hukuken de işçiyi işe başlatacak olan asıl işveren değil, alt işverendir. İşe iadeye bağlı boşta geçen süre ücreti, işe başlatmama tazminatı gibi malî sonuçlardan ise müteselsil sorumluluk söz konusudur. Kaldı ki müteselsil borçlulukta birlikte sorumluluk dış ilişkide alacaklıya (işçiye) karşıdır. Borçlular arasındaki iç ilişkide rücu esasları gereğince asıl işveren (idare), ödediği tutar için alt işverene rücu edebilecektir. Nasıl ki diğer müteselsil sorumluluk hallerinde işverenlerin arabuluculuk sürecinde birlikte hareket

11 22. HD. 18.01.2018 T., 2017/45379; 2018/845 K. (Çalışma ve Toplum, 2018/3); 22. HD. 05.04.2012 T., 2012/1966 - 6464 (Çalışma ve Toplum, 2013/1).

12 Alt işverenlik (taşeronluk) hakkında geniş bilgi için bkz. Süzek, (2018): 162 vd.; Çelik, Caniklioğlu ve Canbolat, (2016): $54 \mathrm{vd}$. 
etmesi aranmıyorsa burada da aynı esas geçerli olmalıdır. Müteselsil sorumluluk medenî yargılama hukuku açısından davada bile zorunlu değil, ihtiyarî dava arkadaşlı̆̆ını beraberinde getiren bir müessesedir (HMK m. 57) (Kuru, 2001: 3340; Pekcanitez ve diğerleri, 2020: 163). Türk Borçlar Kanunu'nun müteselsil borçlulukta alacaklı ile borçlular arasında dış ilişkiyi düzenleyen 163. maddesi açıktır: Alacaklı, borcun tamamının veya bir kısmının ifasını, dilerse borçluların hepsinden, dilerse yalnı birinden isteyebilir (f. 1). Hal böyleyken ve arabuluculuk taraf iradelerinin egemen olduğu, esnek bir süreç iken anlaşmanın o sözleşmenin taraflarından öte 3 . kişi asıl işverenin de rızasına bağlanması kanımızca isabetli olmamıştır. Başvurunun her iki işverene karşı birlikte yapılması şart kılınsa dahi, süreçte birlikte hareket etmeleri ile anlaşmanın asıl ve alt işverenin iradelerinin uyuşması şartına bağlanması zorunluluğu kaldırılmalıdır.

Tekrar vurgulamak gerekir ise, işverenlerin birlikte hareket etmesi ve iradelerin aynı yönde olması zorunluluğu tüm alt işverenlik ilişkilerine dayalı işçilik alacağı talepleri ve müteselsil sorumluluk halleri için değil, işçinin işe iadesi konusundaki uyuşmazlıklar bakımındandır. Diğer müteselsil (zincirleme, birlikte) sorumluluk hallerinde anlaşma toplantılara katılan ve anlaşma sağlayan müteselsil borçlu açısından sonuç doğuracaktır (Ekmekçi ve diğerleri, 2018: 148149).

\subsubsection{Komisyon Üyelerinin Sorumluluğu}

Anayasa'nın 40. maddesi gereğince kişinin, resmî görevliler tarafından vâki haksız işlemler sonucu uğradığı zarar, kanuna göre, Devletçe tazmin edilir. Devletin sorumlu olan ilgili görevliye rücu hakkı saklıdır (f. 3). Nitekim Hukuk Uyuşmazlıklarında Arabuluculuk Kanunu'nda açıkça düzenlendiği üzere, komisyon üyelerinin arabuluculuk faaliyeti kapsamında yaptıkları işler ve aldıkları kararlar sebebiyle tazminat davaları ancak Devlet aleyhine açlabilmektedir (6325/m. 15/f. 9). Devlet ödediği tazminattan dolayı görevinin gereklerine aykırı hareket etmek suretiyle görevini kötüye kullanan üyelere ödeme tarihinden itibaren bir yıl içinde rücu eder. Bu düzenleme Hukuk Uyuşmazlıklarında Arabuluculuk Kanunu Yönetmeliği'nin 18. maddesinin 8. fikrasında "komisyon üyelerinin arabuluculuk faaliyeti kapsamında yaptıkları işler ve aldıkları kararlar sebebiyle açılacak tazminat davaları, ancak Devlet aleyhine açılabilir. Devlet ödediği tazminattan dolayı görevinin gereklerine aykırı hareket etmek suretiyle görevini kötüye kullanan üyelere ödeme tarihinden itibaren bir yıl içinde rücu eder" hükmüyle tekrarlanmıştır. Devlet aleyhine tazminat davası açılması hâlinde mahkeme ilgili komisyon üyelerine davayı re'sen ihbar edecektir (f. 9).

Yine Arabuluculuk Kanunu Yönetmeliği'ne göre, arabuluculuk sürecinde karar almaya tam yetkili komisyon üyeleri bu görevleri uyarınca aldıkları kararlar ve yaptıkları işlemler nedeniyle görevin gereklerine aykırı davrandıklarının mahkeme kararıyla tespit edilmesi dışında, mali ve idari yönden sorumlu tutulamazlar (m. 18/f. 7). Söz konusu düzenlemenin idarecileri Sayıştay denetimi kaygısından kurtaracağı, idareyi ve kararları uygulayacak olan sorumluları rahatlatan bir hüküm olduğu, ancak yıllardır süregelen alışkanlıkların kolay değiştirilemediği, uyuşmazlığın dava sırasında idare aleyhine sonuçlanmasının kuvvetle muhtemel görülmesi halinde bile ve emsal kararlar olmasına rağmen Sayıştay denetiminde sorun yaşamaktan çekinen idarecilerin talepleri reddettikleri, komisyon üyelerinin anlaşma yönünde karar almada tereddüt ettikleri değerlendirilmektedir (Karaköse Üçtepe, 2020: 144-145). Yine de komisyon üyelerinin her türlü kusurunun rücu sebebi olarak düzenlenmeyip, bunun sadece görevin gereklerine aykırı davranarak görevini kötüye kullanma haliyle sinırlanması ve mahkeme kararının aranması isabetlidir ve üyelerin daha rahat karar alabilmesini, çalışma imkânı 
bulabilmesini sağlayıcı niteliktedir. Tabiatıyla bu sayede idarenin taraf olduğu özel hukuk uyuşmazlıklarında da arabuluculuğun amaca ulaşma şansı artabilecek ve bu yöntemin kullanılması teşvik edilecektir. (Çapar, 2020: 2531)

Genel olarak kamu görevlilerinin kusuru; görevle ilgili, gerçekleştirdiği hizmet kapsamındaki kusuru olan "görev kusuru", diğeri görevle ilgisi olmayan "șahsî kusur"dur. Hizmetle bir ilgisi olmayan şahsî (kişisel) kusurda ilgili kamu görevlisi bizzat ve doğrudan doğruya sorumlu iken, kamu görevlisinin göreviyle ilgili bir kusurunun bulunması halinde idarenin sorumluluğu doğduğunda Devlet ödediği tazminatı kusuru oranında kamu görevlisine rücu edebilmektedir. Görev kusurunun, idarenin yürüttüğü faaliyet esnasında yahut bir hizmetin yerine getirilmesinde organizasyonun gereği gibi işlememesi, aksaması, geç ya da kötü işlemesi olan "hizmet kusuruyla" karıştırılmaması gerekmektedir. Esasen hizmet kusuru daha geniş bir kavram olup, görev kusurunun olduğu her durumda idarenin hizmet kusurundan söz edilebilir ise de, tersine bir genellemeyle hizmet kusurunun olduğu her olayda görev kusurunun varlığından söz edilemez. (Çınarlı, Göncü Döner ve Azak, 2021: 32-36; Gözler ve Kaplan, 2018: 355-356)

Bir zararın ortaya çıkması halinde tazminat yaptırımıyla karşılanan "kusur sorumluluğu" bakımından kusur türleri kasıt ve ihmaldir. Kasıtta hukuka aykırı davranışın bilerek, isteyerek meydana getirilmesi, sonucun da fail tarafından tasarlanıp bilinmesi söz konusudur. İhmalde ise hukuka aykırı sonuç istenmemekle birlikte o zararlandirıcı sonucun ortaya çıkmaması için koşulların gerektirdiği, durumun gerekli kıldığı gerekli özen gösterilmemekte, bunu önlemek adına gerekli tedbirler alınmamaktadır (Eren, 2017: 599 vd.). İdarenin arabuluculuk komisyonu üyelerinin sorumluluğunu gerektiren hal, "kasıt" türündeki kusurdur.
Türk Ceza Kanunu'nun 257. maddesinin 1. fikrasına göre, kanunda ayrıca suç olarak tanımlanan haller dişında, görevinin gereklerine aykırı hareket etmek suretiyle, kişilerin mağduriyetine veya kamunun zararına neden olan ya da kişilere haksız bir menfaat sağlayan kamu görevlisi, altı aydan iki yıla kadarhapis cezası ile cezalandırılır. Ceza hukuku açısından, kamu görevlisinin kamu yararına kullanması için kendisine verilen yetkiyi, kamunun yararına olarak değil, özel menfaat güderek kötüye kullanılması, yetki aşımı görevin gereklerine aykırılık mahiyetindedir. Bunların yanında kamu görevlisinin takdir yetkisini, yetkinin tanınmasındaki amacın dışına çıkarak mesela öç almak, kişisel üstünlüğünü kanıtlamak gibi saiklerle kötüye kullanması da, diğer unsurların gerçekleşmesi halinde görevi kötüye kullanma olarak kabul edilmelidir (Ergün Okuyucu, 2009: 8; Sevük Yokuş, 2020: 775). Ceza hukuku bakımından da bu suçun manevî unsuru kasıt olup, kamu görevlisinin özensizliği gibi taksirle işlenmesi mümkün değildir (Tezcan, Erdem ve Önok, 2019: 1117; Kartal Memiş, 2013: 1388-1389; Özbek, Doğan ve Bacaksız, 2019: 1136). 257. maddenin gerekçesinde de belirtildiği gibi, kamu faaliyetleri ve hizmetlerinin eşitliğe, liyakate, adalete uygun yürütüldüğü konusunda toplumda egemen olan inancın ve güvenin sarsılmaması gereklidir. Kamu görevinin gereklerine aykırı olan her fiil cezaî müeyyide gerektiren bir suç olmayıp, görevin gereklerine aykırı davranış belli şartların varlığı halinde görevi kötüye kullanma suçunu oluşturabilmektedir. Öyle ki bu davranış neticesinde kişilerin mağduriyetinin ortaya çlkması veya kamunun ekonomik bakımdan zararına neden olunması veya kişilere haksız kazanç sağlanmış olması gereklidir. Türk Ceza Kanunu yönünden "mağduriyet" kavramı, "zarar"dan daha geniş bir anlama sahip olmakla birlikte, konumuz bakımından bir zararın tazmin edilmesi ve ödenen tutar açısından ilgili komisyon üyelerine rücu edilmesi söz konusudur. Dolayısıyla rücu 
davasının konusu sonuçta bir para alacağıdır ve dava, eda davası niteliğindedir.

Türk Ceza Kanunu'nda görevin gereklerine aykırı hareket etme fiili tek başına suç teşkil etmeyip, bunun sonucunda kamunun zararının doğması (yahut kişilerin mağduriyetine yol açılması gibi) sonuçlar aranmaktadır (Sevük Yokuş, 2020: 774). 6325 sayılı Kanun uyarınca Devlet ödediği tazminat için komisyon üyesine veya üyelerine rücu ettiğine göre, ortada bir zararın/mağduriyetin bulunduğu açıktır. İdarî yargıda Devlet aleyhine açlan tam yargı davasında verilecek karar, zarar miktarının belirlenmesi bakımından önemlidir. $\mathrm{Bu}$ nedenle içtihatlarda da işaret edildiği üzere kararın kesinleşmesi beklenmelidir (Çınarlı ve diğerleri 2021: 160-162). Zaten ancak ödenen tazminat için kamu görevlisine rücu edileceğine göre idarenin davalı tarafta yer aldığı önceki tazminat davasında verilen kararın kesinleşmiş olması olağandır.

Zarar gören ile Devlet arasındaki bu davanın, ilgili komisyon üyelerine re'sen ihbar edilmesi gerekmektedir. Genel olarak, medenî yargılama hukukunda taraflardan biri davayı kaybettiği takdirde, üçüncü kişiye veya üçüncü kişinin kendisine rücu edeceğini düşünüyorsa, tahkikat sonuçlanıncaya kadar davayı üçüncü kişiye ihbar edebilir; dava kendisine ihbar edilen kişi, davayı kazanmasında hukukî yararı olan taraf yanında davaya katılabilir (HMK m. $61,63)$. İhbar etkisinin rücu hakkının sonucu olarak doğduğu hallerde, dış ilişkide alacaklıya karşı hakkı karşılamakla yükümlü olan kişi, aslında o borçtan başka bir kişiyle iç ilişkisinde kısmen veya tamamen sorumlu değil ise, ödediği tutarı dönüp söz konusu üçüncü kişiden talep etme imkânına sahiptir (Atall, 2007: 183-184; Musielak, 2005: 219-220). Burada daha sonra rücu etmesi gündeme gelebilecek olan Devlettir; dolayısıyla davanın bu tarafça ihbar edilmesi mümkündür.

Davanın ihbar edildiği kişi derdest davada taraf sıfatı kazanmamaktadır (Pekcanıtez ve diğerleri, 2020: 175, 177) ve onun hakkında hüküm verilmemektedir. Ancak daha sonra bu davanın taraflarından biri ile ihbar edilen arasında bir rücu meselesi doğabileceğinden, üçüncü kişi o tarafın davayı kazanmasına yardımcı olabilmekte, böylelikle ileride kendisi açısından ortaya çıkabilecek aleyhe durumları da bertaraf etmeye çalışmaktadır. Ayrıca davanın ihbarı ile ihbar etkisi doğacak olup, bu etki hem davanın ihbar edildiği üçüncü kişiye hem de ileride açılması muhtemel rücu davasına bakacak mahkemeye yöneliktir. Artık üçüncü kişi, ihbar edilen davada ihbar eden kişi aleyhine verilmiş hükmün kendi açısından sonuç doğurmasına da katlanmak durumundadır ve o hükmün doğruluğunu tartışamamaktadır (Atalı, 2007: 141 vd.). Devlet aleyhine açlan tazminat davasında, arabuluculuk komisyonu üyeleri üçüncü kişi konumundadır. Yani dava, zarar gören tarafından devlete karşı açıldığından bu davanın davacısı da davalısı da ilgili komisyon üyeleri değildir. Komisyon üyelerinin taraf sıfatı, kendilerine husumet yöneltilerek Devlet tarafından açılacak rücu davasında karşımıza çıkmaktadır. O yüzden henüz davada taraf olmayan arabuluculuk komisyonu üyelerinin de, tesadüfe bırakılmadan, davadan haberdar edilmeleri amacıyla Yönetmelik'te davanın mahkeme tarafından re'sen ilgili komisyon üyelerine ihbar edilmesi benimsenmiştir. İdarî Yargilama Usulü Kanunu'nun 31. maddesinde üçüncü şahısların davaya katılması ve davanın ihbarı Hukuk Muhakemeleri Kanunu hükümlerine atıfla düzenlenen müesseseler arasındadır. Ancak HMK'da taraflardan birisinin davayı ihbarı esas alınmış olup, İdarî Yargllama Usulü Kanunu'nun 31.maddesinde ise davanın mahkeme veya hakim tarafından re'sen ihbar edilmesine açıkça yer verilmiştir. Arabuluculuk mevzuatındaki hüküm de bununla uyumludur. 0 halde, mahkeme tarafin ihbarını beklemeden davayı idarenin arabuluculuk komisyonu üyelerine kendiliğinden ihbar edebilecektir. Hatta bu, mahkeme bakımından mevzuatın yüklediği bir görevdir. İhbar üzerine komisyon üyeleri veya üyesi davalı yanında davaya katılarak onun davayı kazanmasına katkı sağlayabilir. Davanın ihbar edildiği 3. kişi komisyon 
üyelerinin hareketsiz kalması yahut davaya katılması, elbette taraf olan Devleti davayı takipten kurtarmamaktadır (Pekcanitez ve diğerleri, 2020: 176).

Özellikle dikkat edilmesi gereken bir konu, kıdem tazminatı bakımından iş mevzuatında getirilen tavan sınırıdır ${ }^{13}$. Tavan sınırını aşan şekilde kıdem tazminatı kararlaştırıldığında, Sayıştay ödemelerin kanuna uygun yapılıp yapılmadığını inceleyip denetleyeceğinden, kanuna aykırı ödemenin kamu zararı niteliğinde tespit edilmesi ihtimal dahilindedir. İş uyuşmazlıklarında kıdem tazminatının yanı sıra ihbar tazminatı, fazla mesai ücreti, yıllık izin ücreti gibi birden çok talep sıklıkla bir arada bulunabileceğinden, anlaşma sağlanan ve anlaşılmayan kalemlerin hangileri olduğunun tutanaklarda açıkça gösterilmesi, kararlaştırılan tutarın neye ilişkin olduğunun anlaşma belgesinde açıkça belirtilmesi önemlidir. Bu konuda komisyon raporları da kapsamlı, denetime elverişli şekilde hazırlanmalıdır. Yine anlaşma belgesindeki tutarın net mi brüt mü olduğu, faiz ödenecekse faizin başlangıcının ve türünün gösterilmesi kamu zararı tartışmalarına meydan vermemek açısından göz önünde bulundurulmalıdır. (Çil, 2018b: 30-31)

Rücu davaları özel hukuk hükümlerine göre adliye mahkemelerinin (asliye hukuk mahkemelerinin) görev alanındadır (Gözler ve Kaplan, 2018: 325; Çınarlı ve diğerleri, 2021: 72).

\section{SONUÇ}

Uyuşmazlıkların dava yoluyla mahkemelerde çözülmesi dışında çözüm yolları da bulunmaktadır. Yargılama yapılarak uyuşmazlıkların çözüldüğü mahkemede ve tahkimde, yargılama başladıktan sonra artık karar verme yetkisi taraflarda olmayı, hakimde veya hakemdedir. Arabuluculuk ise temeli tarafların aralarındaki sorunu

13 Kıdem tazminatlarının yıllık miktarı, Devlet Memurları Kanununa tabi en yüksek Devlet memuruna 5434 sayılı T.C. Emekli Sandığı Kanunu hükümlerine kendilerinin müzakere etmesine dayanan, ortak kazanımı gözeten ve sonuç üzerinde onların tam egemenliğini sağlayan bir alternatif çözüm yöntemidir. Müzakereler, bağlayıcı bir karar verme yetkisi bulunmayan tarafsız bir üçüncü kişi olan arabulucu yardımıyla, yasal düzenlemelerle de yapılandırılmış ve kural olarak gizli bir süreçte yürütülmektedir. İdarenin de kamu gücünü kullandığı idarî işlemler dışında, özel hukuk ilişkilerine ve bunlardan doğan uyuşmazlıklara taraf olması mümkündür. Arabuluculuk Kanunu'na göre tarafların üzerinde serbestçe tasarrufta bulunabilecekleri, mutlaka bir mahkeme hükmüyle çözümü şart olmayan iş ve işlemlerden doğan özel hukuk uyuşmazlıkları, taraflardan biri idare olsa dahi arabuluculuğa elverişlidir. İdarenin taraf olduğu uyuşmazlıkların alternatif çözüm yollarıyla ortadan kaldırılması esasen Türk hukuk sistemine yabancı olmayıp, örneğin 1920'li ylllarda kabul edilen yasalarda dahi müzakere, sulh, arabuluculuk yöntemlerine ilişkin düzenlemeler görülebilmektedir.

Çalışmamızın başlıca normatif düzenlemelerini içeren 6325 sayılı Hukuk Uyuşmazlıklarında Arabuluculuk Kanunu'nun arabuluculuğa egemen olan gönüllülük, tarafların eșitliği, gizlilik gibi ilkeleri idarenin katılımı halinde de geçerli olup, idarenin karşı taraf üzerinde bir üstünlüğü, kamu gücünü kullanarak onu bir sonuca, benimsemediği bir anlaşmaya zorlaması mümkün değildir. $\mathrm{Bu}$ kanun hem genel bütçe kapsamındaki kamu idarelerini hem özel bütçeli idareleri hem de düzenleyici ve denetleyici kurumlar ile sosyal güvenlik kurumlarını kapsamına almaktadır. Yine mahalli idareler ve bu idareler tarafından kurulan işletmeleri, özel kanunla kurulmuş diğer kamu kurum, kurul, üst kurul ve kuruluşları, kamu iktisadi teșebbüsleri ile bunların bağlı ortaklıkları, müessese ve işletmelerini, sermayesinin yüzde ellisinden

göre bir hizmet yılı için ödenecek azami emeklilik ikramiyesini geçemez (1475 sK. m. 14; 4857 sK. m. 120). 
fazlası kamuya ait diğer ortaklıkları "idare" tanımına dahil saymaktadır. Dolayısıyla idarenin hukuk uyuşmazlıklarının alternatif yollarla çözümünü içeren önceki yasal düzenlemelerden çok daha geniş bir kapsama sahiptir. Süreçte idarenin komisyonla temsili zorunludur. Arabuluculuk komisyonu üst yönetici tarafından belirlenen iki üye ile hukuk birimi amiri veya onun belirleyeceği bir avukat ya da hukuk müşaviri olmak üzere üç kişiden oluşmaktadır. Komisyon üyelerinin görev süresi iki yıl olmakla birlikte, süresi dolan üye yeniden seçilebilmektedir.

İdarenin komisyon yerine bir vekille, avukatla temsili mümkün değildir. Keza İş Mahkemeleri Kanunu'na göre iş uyuşmazlıklarına özgü olarak kabul edilen işverenin yazılı bir belgeyle yetkilendirdiği çalışanının görüşmelerde işvereni temsil etme ve son tutanağı imzalayabilme imkânı, idare açısından uygulama kabiliyeti taşımamaktadır. Süreç anlaşma, anlaşmama yahut kısmen anlaşma gibi ne şekilde sonuçlanırsa sonuçlansın kararın oybirliğiyle alınması gerekmektedir ve üyeler karar alma konusunda tam yetkilidir. Kararın idarenin üst yöneticisine ayrıca onaylatılması gibi bir yöntem söz konusu değildir. Müzakereler sonunda komisyon, düzenlediği gerekçeli raporu beş yıl boyunca saklar. Üyelerin arabuluculuk faaliyetinde serbestçe müzakere edip karar verebilmeleri için kararları ve işlemleri nedeniyle görevin gereklerine aykırı davrandıklarının mahkeme kararıyla tespit edilmesi dışında, malî ve idarî yönden sorumlu tutulamayacakları benimsenmiştir. Uygulamada ise bu hususta tereddütlerin olduğu, sorumluluk doğabilir kaygısıyla deyim yerindeyse "risk almaktan" kaçınıldı̆̆ anlaşmaya yanaşılmadığı gözlenebilmektedir. Oysa arabuluculuk çözüm yolu sirf fiilen bir oturuma katılmaktan ibaret görülmemelidir. Arabulucunun da yardımı ile etkili, sağlıklı bir müzakere sürecinin yürütülmesi ve uyuşmazlığın kazan-kazan kuralına dönük, tatmin edici bir anlaşmayla giderilmesi hedeflenmektedir. Sayıştay denetimlerinde de arabuluculuk sürecinin esas ve ilkeleri göz önünde tutularak inceleme ve değerlendirmelerde bulunulmalıdır.

İdarelerin doğrudan doğruya işveren sıfatıyla işçi çalıştırmasının yanında, hizmet alım yoluyla yüklenicilere yaptırdıkları işlerde de işçiler istihdam edildiğinden, idarenin taraf olduğu özel hukuk uyuşmazlıklarının başında iş uyuşmazlıkları gelmektedir. Kanuna, bireysel veya toplu iş sözleşmesine dayanan işçi veya işveren alacağı ve tazminatı ile işe iade talebiyle açılan davalarda, arabulucuya başvurulmuş olması dava şartıdır. $\mathrm{Bu}$ doğrultuda idare kendisinin ișveren sıfatıyla katıldığı arabuluculuk faaliyeti dışında, hem müteselsil (birlikte) sorumluluk nedeniyle alacak talepli başvurularda hem de ișe iade davalarının öncesinde arabuluculukta yer almaktadır. İşverenlerin birlikte sorumluluğuna dayalı örneğin alt işverenlik ilişkilerinde alacak talepli arabuluculuk faaliyetleri yönünden onların birlikte hareket etme ve aynı yönde karar alma zorunluluğu bulunmamaktadır. Ne var ki işe iade talebiyle arabulucuya başvurulduğunda anlaşma sağlanabilmesi için asıl işveren ile alt işverenin görüşmelere birlikte katılarak iradelerinin birbirine uygun olmasının aranması, alt işverenliğin hukukî niteliğine de arabuluculuk sürecinin ilkelerine de uygun düşmemektedir. Geçerli bir alt işverenlik ilişkisinde asıl işveren iş sözleşmesinin tarafı olmadığı halde, adeta işçinin kendi işvereninin onu yeniden işe başlatıp başlatmaması sözleşmeye taraf olmayan bir üçüncü kişinin inisiyatifine bırakılmaktadır. Arabuluculuk gönüllülük esasına dayalı, iradî bir alternatif çözüm yolu olup sonuç üzerinde o ilişkinin taraflarının kendi iradeleri belirleyicidir. Asıl işverenlerin işçilik alacaklarından işçiye karşı yasal olarak birlikte sorumlu tutulmaları, asıl işverenlere iş sözleşmesini fesih yetkisi bahşetmez iken, işçinin işe iadesi hakkında karar verici olmaları kabul edilemez. İş Mahkemeleri Kanunu'nun 3. maddesiyle getirilen bu düzenlemenin değiştirilmesi gerektiği kanaatindeyiz. 


\section{KAYNAKÇA}

ADB arabuluculuk istatistikleri. Erișim adresi https://adb.adalet.gov.tr/Home/SayfaDetay/ arabuluculuk-istatistikleri

Atall, M. (2007), Medenî Usûl Hukukunda Davanın İhbarl, Ankara.

Canbolat, T. (2018), İş Hukuku Bakımından Arabuluculuk, Yargıtayın 150. Kuruluş Yıl Dönümü Etkinlikleri Kapsamında Yargıtay Başkanlığı ile Ankara Yıldırım Beyazıt Üniversitesi Hukuk Fakültesinin Birlikte Düzenlediği, Arabuluculuğun Geliştirilmesi Uluslararası Sempozyumu, Ankara.

Canbolat, T. (2020), İş Hukuku Alanında Arabuluculuk, Arabuluculuk Zirvesi -II-, İstanbul. Y. Güllüoğlu Altun (Ed.).

Çalışma ve Toplum Dergisi (2013/1), Yargıtay kararları. Erişim adresi https://www. calismatoplum.org/yargitay-karari/asilisveren-alt-isveren-arasinda-ise-iadedavalarinda-mecburi-dava-arkadasligininbulunmasi

Çalışma ve Toplum Dergisi (2018/3), Yargıtay kararları. Erişim adresi https://www.calisma toplum.org/yargitay-karari/davanin-asilisverene-de-yoneltilmesi-icin-sureverilmesinin-gerekmesi

Çapar, A. (2020), İdarenin Taraf Olduğu Hukuki Uyuşmazlıkların Çözümünde Arabuluculuk Yöntemi, Journal of Social and Humanities Sciences Research, 7(59), 25262535.

Çınarlı, S., Göncü Döner, M. S. ve Azak, K. (2021), Kamu Görevlilerine Rücu Davaları, Ankara.

Çelik, N., Caniklioğlu, N. ve Canbolat, T. (2016), İş Hukuku Dersleri, İstanbul.

Çil, Ş. (2018a), Dava Şartı Olarak Zorunlu Arabuluculuk, İş Mahkemeleri Kanunu ile
Getirilen Yeni Düzenlemeler ve Arabuluculuk, İntes Yayınları, Yayın No: 28, Ankara.

Çil, Ş. (2018b), Zorunlu Arabuluculuk Görüşmelerinde Son Tutanak, İntes, İnşaat Sanayi Dergisi, S. 165.

Ekmekçi, Ö., Özekes, M. ve Atalı, M. (2018), Hukuk Uyuşmazlıklarında İhtiyarî ve Zorunlu Arabuluculuk, İstanbul.

Eren, F. (2017), Borçlar Hukuku Genel Hükümler, Ankara.

Ergün Okuyucu, G. (2009). Görevi Kötüye Kullanma Suçu, TBB Dergisi, S. 82.

Erzurumlu, N. (2015), 659 Sayll Kanun Hükmünde Kararname'ye Göre Adlî Uyuşmazlıklarda Sulh, (Yüksek Lisans Tezi, Yıldırım Beyazıt Üniversitesi, Ankara). Erişim adresi https://tez.yok.gov.tr/UlusalTez Merkezi/tezSorguSonucYeni.jsp

Gilles, P. (2008), Tasarı Üzerine Genel Değerlendirme ve Tartıșma, Medenî Usûl ve İcra-İflâs Hukukçuları Toplantısı - VI, Medenî Usûl Hukukunda Kanun Yolları ve Arabuluculuk Kanun Tasarısı, İzmir/ Çeşme 19-20 Ekim 2007, TBB Yayınları, Ankara.

Goodman, A. (2016), Arabuluculuğa Hazırlanmak, Arabuluculuktan Yararlananlar İçin Rehber, UK Adalet Bakanlığı Yayın İşleri Daire Bașkanlığl, Erișim adresi https://adb. adalet.gov.tr

Gözler, K. ve Kaplan, G. (2016), Kısa İdare Hukuku, Bursa.

Gözler, K. ve Kaplan, G. (2018), İdare Hukukuna Giriş, Bursa.

Green Fishman, R. (2002), Mediator Neutrality: How is it possible?, Erişim adresi https://www.mediate.com/articles/green2. $\mathrm{cfm}$ 
Hasoğlu, A. (2016), İdare Hukukunda Alternatif Uyuşmazlık Çözüm Yolları, AÜHF Dergisi, C. 65, S. 4.

Huerta, A. L. (2004), Why Mediation, Erişim adresi https://www.mediate. com/articles/ huertaL1.cfm

Karaarslan, M. (2019), İdarenin Taraf Olduğu Uyuşmazlıkların Alternatif Uyuşmazlık Çözüm Yöntemleri ile Giderilmesi, TBB Dergisi, S. 140.

Karaköse Üçtepe, R. (2020), İdari Uyuşmazlıklarda Alternatif Çözüm Yolu Olarak Arabuluculuk, Arabuluculuk Zirvesi -II-, İstanbul. Y. Güllüoğlu Altun (Ed.).

Kartal Memiş, P. (2013), Görevi Kötüye Kullanma Suçu, Prof. Dr. Nur Centel'e Armağan, Marmara Üniversitesi Hukuk Fakültesi, Hukuk Araştırmaları Dergisi, C. 19, S: 2, Özel Sayı.

Kurt, R. (2018), İş Yargısında Arabuluculuk, TBBD, S: 135.

Kuru, B. (2001), Hukuk Muhakemeleri Usulü, C. III, İstanbul.

Legal Information Institute, 2017, Alternative Dispute Resolution, Erişim adresi https:// www.law.cornell.edu/wex/alternativedispute resolution

Musielak, H.J. (2005), Grundkurs ZPO, München.

Odaman, S. ve Karaçöp, E. (2018), İş Hukukunda Zorunlu Arabuluculuk Müessesesinin Bugünü ve Geleceğine İlişkin Genel Bir Değerlendirme, Sicil, S. 39. Erişim adresi https://www.mess.org.tr/media/files/ 6835_A3WK6F5Z5Ysicil_02.2018.pdf

Özbek, M. (2005), İdarî Uyuşmazlıkların Çözümünde Yargılama Dışı Usuller I, http:// tbbdergisi.barobirlik.org.tr/m2005-56-105
Özbek, V. Ö., Doğan, K. ve Bacaksız, P. (2019), Türk Ceza Hukuku Özel Hükümler, Ankara.

Özdemir, M., Süral, P. ve Odaman, S. (2005), Türk Yargı Sisteminde Kalite: Yargı Sisteminin Sorunlarına Çözüm Önerileri, Kamu Yönetiminde ve Kamu Hizmetlerinde Kalite, Hizmet İş Sendikası Eğitim Yayınları, Yayın No: 36, Ankara. Erişim adresi file:///C:/ Users/EVPC/Downloads/kamukalite\%20(1).pdf

Pekcanitez, H. (2008), Hukuk Uyuşmazlıklarında Arabuluculuk Kanun Tasarısının Tanıtımı, Medenî Usûl ve İcra-İflâs Hukukçuları Toplantısı - VI, Medenî Usûl Hukukunda Kanun Yolları ve Arabuluculuk Kanun Tasarısı, İzmir/Çeşme 19-20 Ekim 2007, TBB Yayınları, Ankara.

Pekcanitez, H., Atalay, O. ve Özekes, M. (2020), Medenî Usûl Hukuku Ders Kitabı, İstanbul.

Sevük Yokuş, H. (2020), Türk Ceza Hukuku Özel Hükümler, Ankara.

Temel Arabuluculuk Eğitimi Katılımcı Kitabı (2019), A. Yeşilırmak, E. K. Kekeç ve A. Bulur (Ed.), Avrupa Konseyi Projesi, Erişim adresi https://adb.adalet.gov.tr

Süzek, S. (2018), İş Hukuku, İstanbul.

Tezcan, D., Erdem, M.R. ve Önok, M. (2019), Teorik ve Pratik Ceza Özel Hukuku, Ankara.

Üstün Fiș, G. (2020), Arabuluculuk Faaliyetlerinde İdarenin Yeri ve Yetkisi, Marmara Üniversitesi Hukuk Fakültesi Hukuk Araştırmaları Dergisi, C: 26, S. 1. Erişim adresi. https://dergipark.org.tr/en/ download/article-file/1097262

Yeşilırmak, A. (2019), Arabuluculuk Nedir? A. Yeşilırmak, E. K. Kekeç ve A. Bulur (Ed.), Avrupa Konseyi Projesi Temel Arabuluculuk Eğitimi Katılımcı Kitabı içinde (26-42 ss.). Erişim adresi adb.adalet.gov.tr 


\section{G. ÜRCAN}

Yıldırım, M. K. (2007), İhtilafların Mahkeme Dışı Usullerle Çözülmesi Hakkında, Prof. Dr. Yavuz Alangoya İçin Armağan, İstanbul. 